\title{
PENINGKATAN FUNGSI VENTILASI OKSIGENASI PARU PADA KLIEN PASCA VENTILASI MEKANIK DENGAN DEEP BREATHING EXERCISE
}

\author{
Priyanto $^{1,2^{*}}$, Dewi Irawaty ${ }^{3}$ Luknis Sabri ${ }^{4}$ \\ 1. Program Studi Ilmu Keperawatan STIKES Ngudi Waluyo Ungaran, Semarang 50513, Indonesia \\ 2. Program Magister Fakultas Ilmu Keperawatan Universitas Indonesia, Depok 16424, Indonesia \\ 3. Fakultas Ilmu Keperawatan Universitas Indonesia, Depok 16424, Indonesia \\ 4. Fakultas Kesehatan Masyarakat Universitas Indonesia, Depok 16424, Indonesia \\ *Email:priyanto_araaf@yahoo.co.id
}

\begin{abstract}
Abstrak
Deep breathing exercise (DBE) merupakan latihan aktifitas paru dengan teknik nafas dalam dan batuk efektif untuk meningkatkan ventilasi oksigenasi. Tujuan penelitian untuk mengidentifikasi pengaruh DBE terhadap fungsi ventilasi oksigenasi (VO) paru pada klien paska ventilasi mekanik. Penelitian ini menggunakan kuasi eksperimen nonequivalent control group yang melibatkan 26 responden untuk kelompok intervensi dan kontrol yang diseleksi dengan metode consecutive sampling. Kelompok intervensi melakukan DBE selama lima hari. Instrumen yang digunakan bedside monitor, peak flowmeter, dan pulse oximetry. Penelitian dilaksanakan di ICU rumah sakit di wilayah Semarang. Hasil penelitian menunjukkan ada perbedaan bermakna fungsi VO paru setelah melakukan DBE pada hari ke-4 dan $5(p=0,018, p=0,004, \alpha=0,05)$. Penelitian ini merekomendasikan penerapan DBE dalam praktik keperawatan kritis untuk meningkatkan pelayanan keperawatan. Profesionalisme keperawatan ditunjukkan melalui intervensi keperawatan yang bersifat mandiri terutama pada penanganan klien post ventilasi mekanik.
\end{abstract}

Kata kunci: deep breathing exercise (DBE), fungsi ventilasi oksigenasi (VO) paru, post ventilasi mekanik

\begin{abstract}
Deep breathing exercise (DBE) is pulmonary activities with deep breath technique and effective cough to restore oxygenation ventilation. The purpose of research was to identify the influence of deep breathing exercises on ventilation oxygenation pulmonary function on client with post mechanical ventilation. This research used quasy experiment nonequivalent control group, involving 26 respondents for each intervention and control group who selected by consecutive sampling method. Bedside monitor, peak flow meter, pulse oximetry were instrument used. The research was conducted on ICU of hospital in Semarang district. The results showed significant difference ventilation oxygenation (VO) pulmonary function after conducting deep breathing exercise (DBE) on day 4 and $5(p=0,018, p=0,004, \alpha=0,05)$. Recommendations of this study as a reference to improve the standard of nursing care through the application of DBE in the practice of critical care nursing. Implications for service quality improvement through an independent professional nursing care.
\end{abstract}

Keywords: deep breathing exercises (DBE), ventilation oxygenation (VO) pulmonary function, post mechanical ventilation

\section{Pendahuluan}

Kegagalan pernapasan merupakan indikasi yang paling umum untuk dirawat di unit perawatan intensif (ICU) rumah sakit. Kegagalan pernapasan merupakan kondisi ketidakmampuan paru menjaga keseimbangan atau homeostatis $\mathrm{O}_{2}$ dan $\mathrm{CO}_{2}$ di dalam tubuh serta ketidakmampuan paru menyediakan $\mathrm{O}_{2}$ yang cukup atau mengurangi tumpukan $\mathrm{CO}_{2}$ di dalam tubuh. Menurut Ignatavicius dan Workman (2006), kegagalan pernapasan lanjut dapat didefinisikan se- bagai kegagalan ventilasi dan atau kegagalan oksigenasi karena berbagai faktor penyebab.

Pemberian bantuan pernapasan dengan pemasangan ventilasi mekanik dapat membantu ventilasi paru untuk meningkatkan oksigenasi dan mencegah kerusakan paru. Menurut Smeltzer, et al. (2008) bantuan tersebut dilakukan untuk memenuhi kebutuhan oksigen, mengurangi kerja pernapasan, dan meningkatkan oksigenasi ke jaringan atau mengoreksi asidosis pernapasan. 
Penggunaan ventilasi mekanik menurut survai multinasional terhadap 5000 klien di Eropa digunakan pada kasus gagal nafas akut (69\%), koma (17\%), gagal nafas kronis (13\%) dan gangguan neuromuskuler (2\%) (Rodriquez, Dojat, \& Brochard, 2005). Bantuan pernapasan harus diberikan secara adekuat sesuai indikasi untuk mencegah kelemahan otot pernapasan karena diistirahatkan (Smeltzer et al, 2008).

Penyapihan (weaning) ventilasi mekanik dilakukan jika sudah ada kemampuan bernafas spontan. Hal ini menjadi salah satu alasan dilakukannya perbaikan fungsi pernapasan (Rodriquez, Dojat, \& Brochard, 2005). Upaya tersebut dilakukan dengan latihan pernapasan untuk memperbaiki fungsi ventilasi dan oksigenasi paru (Ignatavicius \& Workman, 2006).

Beberapa jenis latihan pernapasan yang dapat dianjurkan untuk pemulihan paru adalah Deep breathing exercises (DBE), diaphragmatic exercise, tehnik pursed lip breathing, dan incentive spirometer (Smeltzer, et al, 2008). Westerdahl, et al (2005) meneliti klien yang melakukan DBE sebanyak $30 \mathrm{kali} /$ jam ketika terjaga setelah 1 (satu) jam paska ekstubasi post CABG, pada hari keempat menunjukkan jumlah atelektasis lebih kecil dan terjadi peningkatan fungsi ventilasi.

DBE terdiri atas 10 kali napas dalam, dibagi dalam 3 (tiga) stase selama setengah jam dengan jeda batuk efektif untuk memobilisasi sekresi. Bila mungkin klien melakukan latihan dengan posisi duduk. Menurut Ignatavicius dan Workman (2006) setelah ekstubasi weaning, klien dianjurkan untuk segera berlatih nafas dalam (DBE) setiap setengah jam dan berlatih duduk semifowler.

Peran perawat ICU diantaranya memantau keluhan sesak nafas, kemampuan ekspansi dada, jumlah pernapasan, mengamati keteraturan dan karakteristik pernapasan serta oksigenasi ke jaringan (Ignatavicius \& Workman, 2006). Tugas penting lainnya penanganan emergency, monitoring fungsi pernapasan melalui observasi fisik dan bedside monitor, edukasi serta pengawasan terhadap perbaikan fungsi ventilasi paru.

DBE merupakan upaya yang dianggap dapat meningkatkan fungsi paru khususnya ventilasi oksigenasi, dan mencegah kegagalan pernapasan berulang serta risiko atelektasis paru post ventilasi mekanik. Tujuan penelitian untuk mengidentifikasi pengaruh DBE terhadap fungsi ventilasi oksigenasi (VO) paru pada klien paska ventilasi mekanik

\section{Metode}

Penelitian kuasi eksperimen dengan pendekatan non equivalent control group ini menggunakan kelompok intervensi dan kontrol. Kedua kelompok memperoleh perawatan dan tindakan medik sesuai prosedur RS. Intervensi dalam penelitian ini adalah penggunaan DBE modifikasi dari Westerdahl, et al. (2005), Ignatavicius dan Workman (2006), dan Anne, Pippin, dan Hill (2009). DBE meliputi 30 kali latihan nafas dalam selama 30 menit dengan diselingi istirahat 30 menit, sebanyak 6 kali sehari pada siang hari selama lima hari.

Penelitian ini dilaksanakan selama delapan di ICU beberapa rumah sakit di Semarang. Sampel penelitian menggunakan jumlah minimal penghitungan rumus uji beda dua proporsi yaitu sebanyak 26 responden (masing-masing kelompok 13 orang) dengan teknik consecutive sampling. Penentuan kelompok dengan systematic random sampling.

Kriteria inklusi responden: usia dewasa, post ventilasi mekanik paska ekstubasi 1 jam, ada riwayat kegagalan pernapasan, dapat bernafas spontan, bersedia menjadi responden dan mengerti instruksi. Kriteria eksklusi meliputi: keadaan umum sangat lemah/ bedrest total; ada nyeri berat; mendapat terapi obat depresan susunan syaraf pusat; ada trakeostomi; ada riwayat pembedahan, dan ada riwayat ventilasi mekanik program maintenance. 
Fungsi Ventilasi Oksigen (VO) paru diidentifikasi melalui pola pernapasan, kapasitas vital paru dan saturasi oksigen. Instrumen penelitian menggunakan bed side monitor, peak flow meter, dan pulse oximetry.

Analisis data menggunakan uji Wilcoxon dan Mann-Whitney untuk mengidentifikasi ada tidaknya perbedaan fungsi ventilasi oksigenasi paru. Spearman correlation dan Fisher exact test untuk mengidentifikasi faktor perancu.

\section{Hasil}

\section{Fungsi Ventilasi Oksigenasi Paru}

Ada peningkatan rerata fungsi ventilasi oksigenasi (VO) paru hari ke-2, 3, 4, dan 5 pada kedua kelompok dengan peningkatan kelompok intervensi lebih tinggi. Pada kelompok intervensi mulai hari ke-3 fungsi ventilasi oksigenasi (VO) paru baik (mean $\geq 9,15$ ), sedangkan pada kelompok kontrol sampai hari ke-5 fungsi ventilasi oksigenasi $(\mathrm{VO})$ paru kurang baik (mean $<9$ ).
Ada perbedaan bermakna antara fungsi VO paru antara 1 (satu) jam paska ekstubasi dengan hari ke3,4 dan 5 setelah intervensi $(\mathrm{p}=0,007 ; \mathrm{p}=0,002$; $\mathrm{p}=0,005, \alpha=0,05)$, tetapi tidak ada perbedaan yang bermakna pada hari ke-2 $(\mathrm{p}=0,191, \alpha=0,05)$.

Ada perbedaan bermakna antara fungsi VO paru antara 1 jam paska ekstubasi dengan hari ke-2, 3, 4 dan 5 pada kontrol $(p=0,020 ; p=0,023 ; p=0,009$; $\mathrm{p}=0,035, \alpha=0,05)$. Ada perbedaan bermakna antara fungsi VO paru hari ke-4 dan 5 pada kelompok intervensi dibandingkan kontrol $(p=0,018 ; p=$ $0,004, \alpha=0,05)$, tetapi tidak ada perbedaan bermakna hari ke-2 dan 3 ( $p=0,691 ; p=0,063, \alpha=$ 0,05 ) (grafik 1).

\section{Pola Pernapasan}

Ditemukan perbedaan bermakna pada pola pernapasan hari ke-4 dan 5 di kedua kelompok ( $\mathrm{p}=$ $0,011 ; p=0,027, \alpha=0,05)$. Mulai hari ke-2 pada kedua kelompok menunjukkan pola pernapasan efektif (skor $\geq 3$ ). Pada hari ke-4 dan 5 pada kelompok intervensi tidak mengalami perubahan karena fungsi VO paru telah efektif (lihat grafik 2).

Grafik 1. Fungsi VO Paru Responden

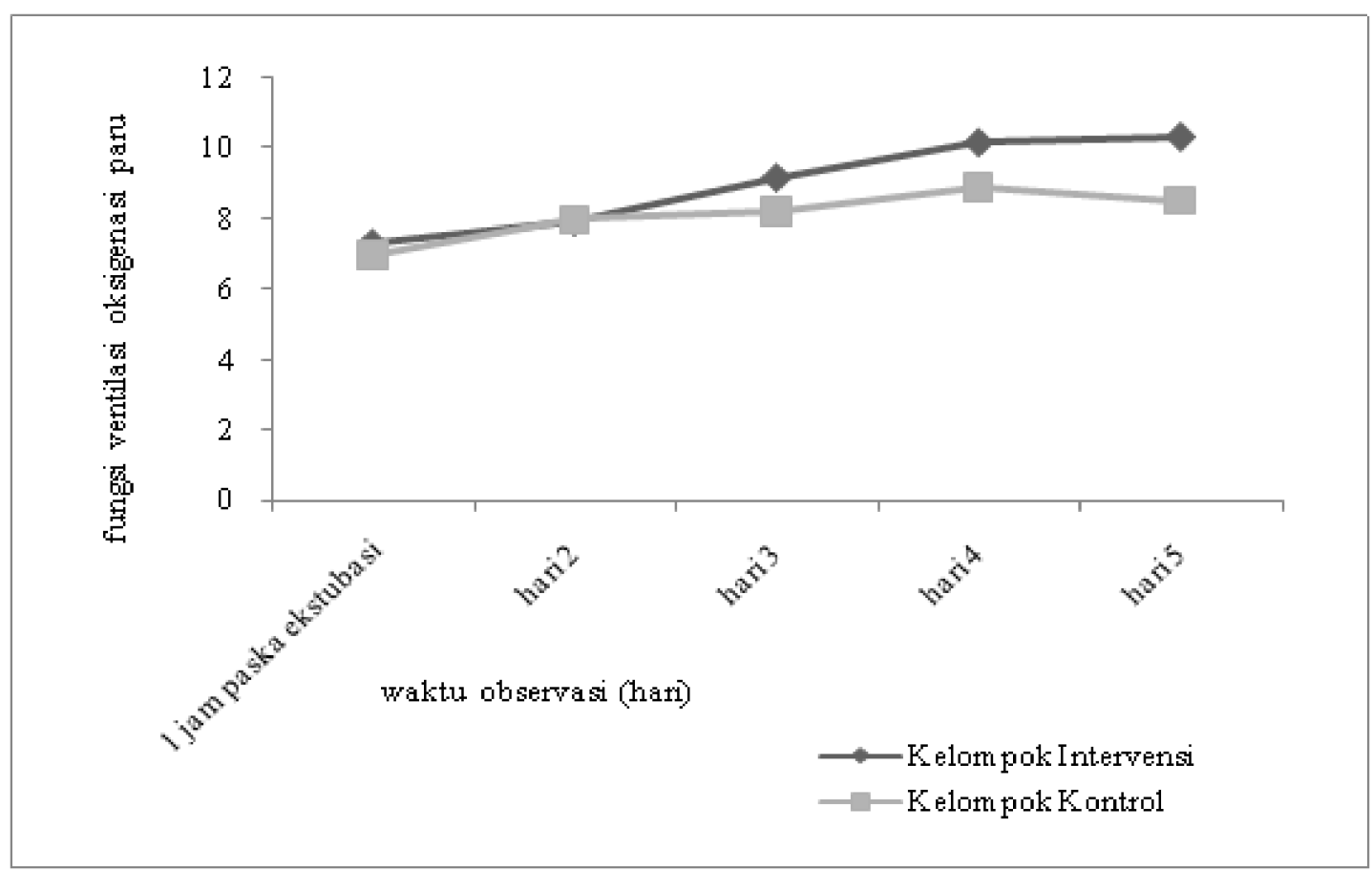




\section{Kapasitas Vital Paru}

Terdapat perbedaan bermakna antara kapasitas vital paru pada hari ke-4 dan 5 pada kelompok intervensi dibandingkan kontrol ( $\mathrm{p}=0,021 ; \mathrm{p}=0,003, \alpha=$ $0,05)$, tetapi ternyata nilai kapasitas vital paru kedua kelompok tidak dapat mencapai nilai normal yaitu $\geq 400 \mathrm{~mL} / \mathrm{min}$ (lihat grafik 3).

\section{Saturasi $\mathrm{O}_{2}\left(\mathrm{SaO}_{2}\right)$}

Tidak ditemukan perbedaan bermakna antara $\mathrm{SaO} 2$ pada hari ke-2, 3, 4 dan 5 pada kedua kelompok $(p=0,915 ; 0,068 ; 0,670 ; 0,100, \alpha=0,05)$. Mulai 1 jam paska ekstubasi sampai hari ke-5 pada kedua kelompok, $\mathrm{Sa} \mathrm{O}_{2}$ telah mencapai nilai normal (> 97\%) (lihat grafik 4).

\section{Faktor Perancu}

Tidak ditemukan pengaruh usia, IMT, kadar $\mathrm{Hb}$ dan jenis kelamin dengan fungsi VO paru $(p=0,1$; $p=0,147 ; p=0,151 ; p=0,136 ; p=0,131 ; p=0,982$; $p=0,614 ; 1,000, \alpha=0,05)$.

\section{Pembahasan}

DBE merupakan salah satu bentuk latihan pernapasan yang dilakukan dengan berbagai modifikasi sesuai dengan kebutuhan. DBE belum banyak dikembangkan dalam pelayanan keperawatan intensif, khususnya bagi klien post ventilasi mekanik. Klien post ventilasi mekanik membutuhkan kemampuan adaptasi terhadap kemampuan ventilasi untuk memberikan suplai terhadap kebutuhan $\mathrm{O}_{2}$ jaringan. Kemampuan ventilasi didukung oleh compliance paru dan kekuatan otot inspirator yang adekuat melalui DBE. Klien paska ventilasi mekanik perlu menerapkan latihan khusus tersebut sesuai kemampuan toleransi fisik yang masih lemah.

Adanya perbedaan yang bermakna antara kedua kelompok pada fungsi VO paru antara 1 jam paska ekstubasi dengan hari ke-2, 3, 4 dan 5 perawatan paska ekstubasi. Hal ini menunjukkan bahwa perawatan yang diterapkan di RS telah sesuai standar dan berhasil meningkatkan fungsi VO paru, walaupun masih termasuk dalam klasifikasi kurang baik sampai hari ke-5.

Beberapa tindakan yang telah diberikan seperti suctioning, oksigenasi nasal kanula, alih baring, pemenuhan kebutuhan dasar lainnya seperti cairan elektrolit, nutrisi, eliminasi, dan personal hygiene yang dilakukan oleh perawat selama ini menjadi bagian dalam pelayanan asuhan keperawatan. Hal ini sejalan dengan Ignatavicius dan Workman (2006), menerangkan bahwa pengawasan selama perawatan paska ekstubasi juga perlu terus dilakukan untuk mencegah kejadian gagal pernapasan berulang dan komplikasi lain yang lebih kompleks.

Grafik 2. Pola Pernapasan Responden

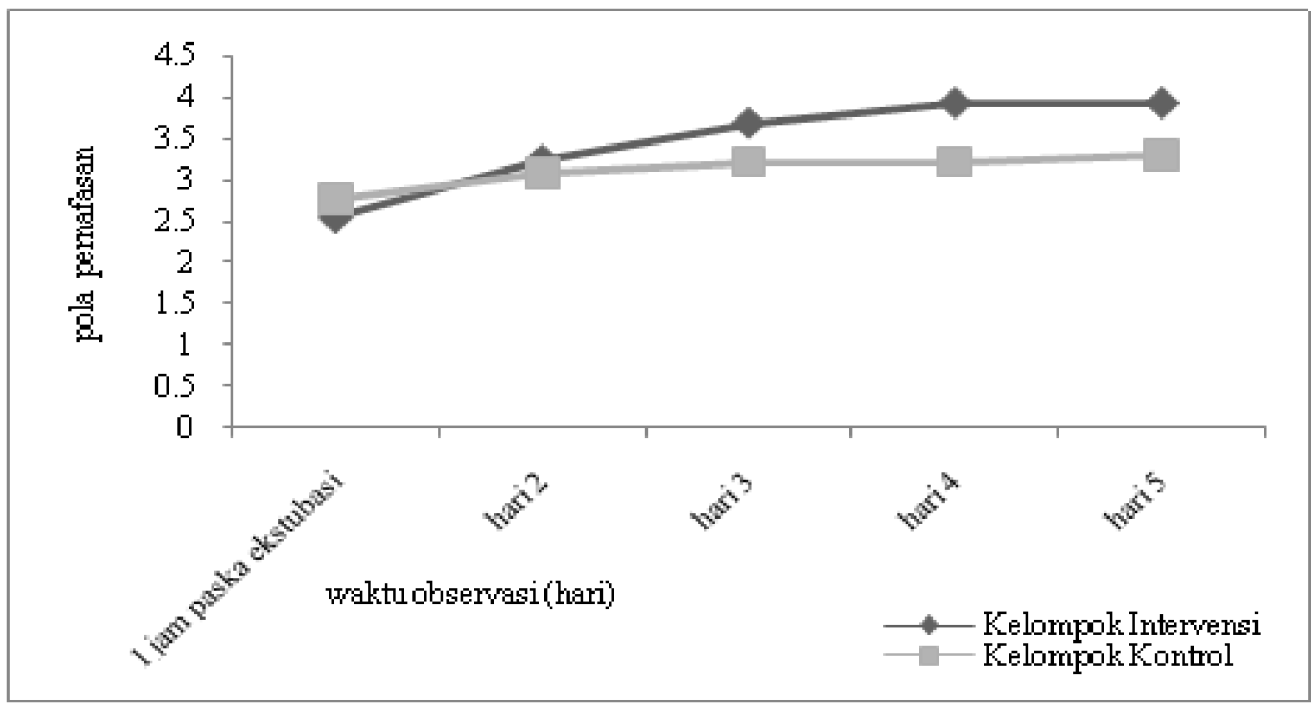


Beberapa tindakan yang telah diterapkan selama ini, berdampak pada peningkatan fungsi VO paru, walaupun sampai hari ke-5 pada kelompok kontrol belum dapat mencapai fungsi VO paru yang normal. Ada perbedaan bermakna antara fungsi VO paru antara 1 jam paska ekstubasi dengan hari ke3, 4 dan 5 setelah melakukan DBE pada kelompok intervensi dan mulai hari ke-3 yang telah mencapai fungsi VO paru baik.

Hal tersebut membuktikan bahwa DBE memberikan efek positif dengan melengkapi prosedur perawatan yang telah diterapkan selama ini. Pencapaian tersebut akibat dari adanya peningkatan kemampuan otot-otot inspirator karena DBE merupakan kegiatan untuk melatih otot inspirasi pernapasan. Padula dan Yeaw (2006) menyebutkan bahwa latihan tersebut bertujuan untuk meningkatkan kemampuan otot inspirator dalam berbagai kondisi yang minimal termasuk pada post ventilasi mekanik.

Roussos dan Zakynthinos (1996 dalam Padula \& Yeaw, 2006) menyebutkan bahwa kondisi yang membutuhkan kekuatan pernapasan yaitu pada kelemahan, kelelahan, istirahatnya otot inspirator yang terlalu lama. Penelitian eksperimen Weiner (Padula \& Yeaw, 2006) menunjukkan bahwa inspirator muscle training berdampak signifikan

Grafik 3. Kapasitas Paru Responden

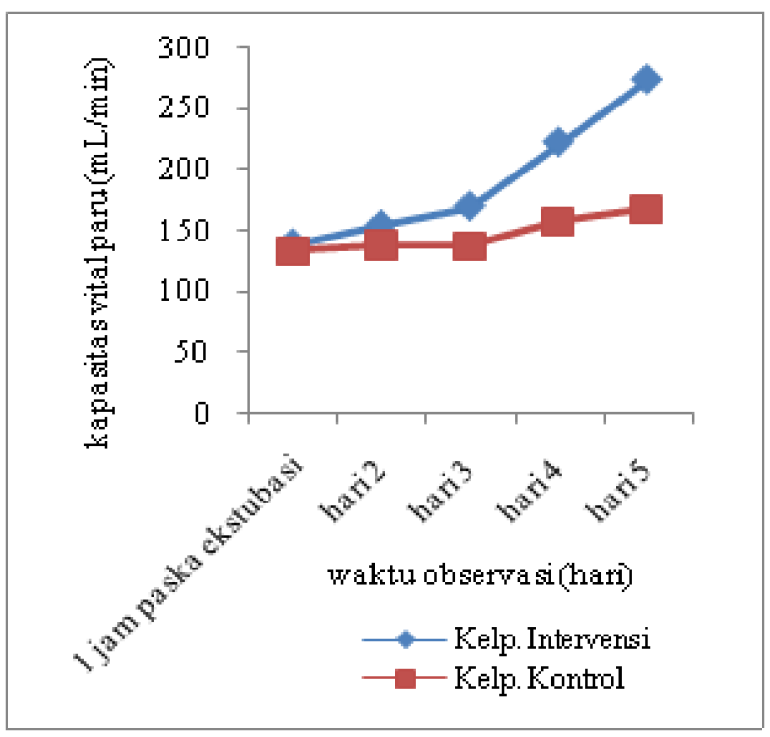

terhadap penurunan keluhan sesak nafas, peningkatan FVC dan mengurangi berbagai gejala gangguan paru.

Sperlich, et al. (2009) juga menyatakan bahwa latihan pernapasan dapat meningkatkan penampilan fisik seseorang yang terbebas dari kondisi kelemahan dan kelelahan. DBE merupakan salah satu latihan pernapasan yang terbukti dapat meningkatkan kemampuan kekuatan otot inspirator, seperti yang telah dikembangkan dalam beberapa penelitian oleh Westerdahl, et al. (2005), El Batanouny, et al. (2009) dan Nusdwinuringtyas (2008).

Otot inspirator yang terlatih akan meningkatkan compliance paru dan mencegah atelektasis. Westerdahl, et al (2005) menyimpulkan bahwa latihan pernapasan dapat dengan cepat menurunkan area atelektasis dan meningkatkan oksigenasi. Compliance dada yang baik memungkinkan ventilasi oksigenasi adekuat sehingga tidak mudah terjadi atelektasis.

DBE mengurangi reaksi simpatik tetapi tidak merubah aktivitas parasimpatik secara signifikan untuk meningkatkan fungsi pernapasan, mengurangi stres, dan kecemasan (Yadav, Singh, \& Singh (2009). Kontrol pernapasan dengan rangsang simpatik dapat memperbaiki ritme dan frekuensi pernapasan tanpa menggangu peran parasimpatik yang berguna menjaga kelangsungan aktifitas pernapasan secara terusmenerus. Sejalan dengan penelitian Westerdahl, et al (2005), yang menyebutkan bahwa DBE dapat meningkatkan fungsi ventilasi dengan perbaikan karakteristik frekuensi dan keteraturan pernapasan.

Di rumah sakit tempat penelitian, peran monitoring melalui bed side monitor dan pulse oximetry telah diterapkan dengan baik dan sesuai prosedur, sedangkan pemeriksaan terhadap kapasitas vital paru jarang dilakukan. Skrining terhadap volume dan kapasitas vital paru penting dilakukan setelah ekstubasi (Westerdahl, et al., 2005). 
Penelitian ini menemukan perbedaan yang bermakna antara fungsi VO paru hari ke-4 dan 5 pada kedua kelompok yang menunjukkan DBE dapat mempercepat perbaikan fungsi VO paru. DBE dapat dianggap sebagai terapi modalitas keperawatan pada konteks perawatan intensif serta menjadi kajian terbaru dalam peranan nyata dan mandiri perawat yang mengedepankan pelayanan keperawatan profesional. Monitor pola pernapasan termasuk keluhan sesak nafas merupakan tugas perawat dalam rangka evaluasi pencapaian perbaikan kondisi klien selama perawatan (Ignatavicius \& Workman, 2006).

Pola pernapasan 1 (satu) jam paska ekstubasi pada kelompok kontrol lebih tinggi dibanding kelompok intervensi. Akan tetapi ada perbedaan bermakna dalam pola pernapasan paru di hari ke-4 dan 5 pada kelompok intervensi. Pada kelompok intervensi terdapat perbaikan pola pernapasan pada hari ke-2.

Menurut Westerdahl, et al (2005), bahwa perbaikan frekuensi dan keteraturan pernapasan merupakan indikator peningkatan fungsi ventilasi. DBE akan mengurangi reaksi simpatik guna memperbaiki pola pernapasan dan mengurangi kontraksi otot inspirasi dan ekspirasi (Yadav, Singh, \& Singh, 2009).

Grafik 4. Saturasi Oksigen Responden

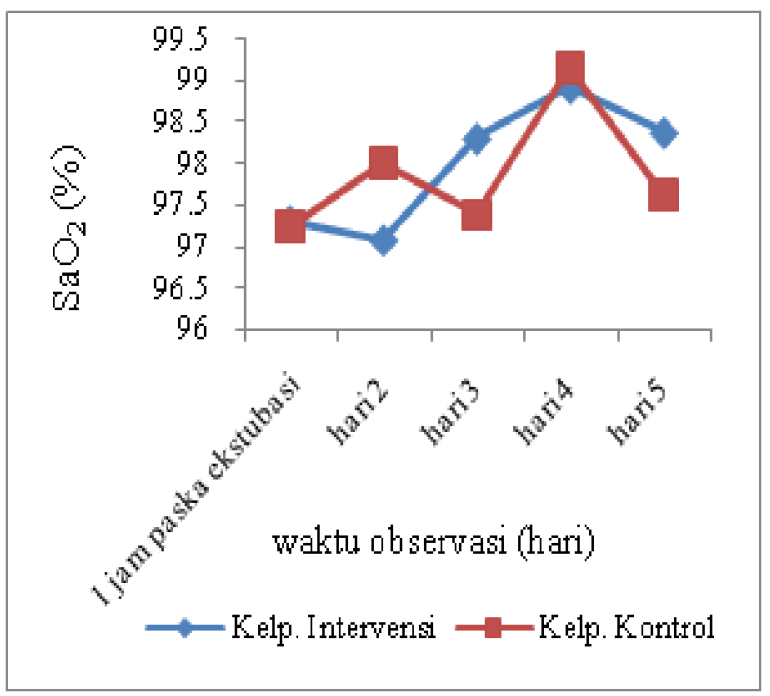

DBE sangat efektif untuk memperbaiki pola pernapasan pada hari ke-4 dan ke-5. Latihan menghirup dan menghembuskan udara secara perlahan dan dalam yang dilakukan secara terusmenerus merupakan kegiatan yang terpola antara kontrol di pusat pernapasan dengan kombinasi kemampuan kinerja otot pernapasan, compliance paru dan struktur rangka dada yang dapat menghasilkan adaptasi terhadap ritme dan kecepatan pernapasan.

Kelemahan otot pernapasan post ventilasi mekanik menyebabkan ketidakmampuan melakukan inspirasi secara optimal, sehingga pemenuhan kebutuhan oksigen menurun. Kesenjangan suplai dan kebutuhan oksigen dapat diatasi dengan melatih otot inspirator melalui DBE.

Menurut Price dan Wilson (2006), bahwa otot pernapasan dikendalikan oleh pusat pernapasan sebagai pusat aspek pernapasan yang terdiri dari neuron dan reseptor pada pons dan medulla oblongata. Perbaikan yang ditimbulkan karena adanya keterhubungan koordinasi otot pernapasan dan desentisasi dypnea.

Menurut Smeltzer, et al. (2008), yang menyatakan bahwa pola pernapasan tertentu menjadi karakteristik dari keadaan penyakit spesifik, mengamati dan mendokumentasikan irama pernapasan dan penyimpangan dari keadaan normal merupakan fungsi keperawatan yang penting.

Ditemukannya perbedaan bermakna pada kapasitas vital paru pada hari ke-4 dan 5 menunjukkan bahwa DBE dapat membantu paru melakukan adaptasi paska ekstubasi. Latihan menghirup dan menghembuskan udara membantu mengembangkan lingkar dada dan melatih otot pernapasan sehingga dapat meningkatkan volume dan kapasitas vital.

Pada kegagalan pernapasan terjadi cedera pada membran alveolar paru yang dapat mengakibatkan kebocoran cairan ke dalam jejaring kapiler hingga mengarah pada ketidakseimbangan ventilasi dan 
oksigenasi. Compliance paru menjadi sangat menurun sehingga terjadi penurunan kapasitas paru, hipoksia dan hipokapnia.

Padula dan Yeaw (2006) dan Nusdwinuringtyas (2008) dalam penelitiannya menjelaskan bahwa melatih otot inspirator dapat membantu meningkatkan kapasitas vital paru. Latihan pernapasan dapat meningkatkan kapasitas vital paru melalui pengukuran nilai FEV1 dan FVC. Terlatihnya otot inspirator akan meningkatkan kemampuan paru untuk menampung udara, sehingga nilai FEV1 akan mengalami peningkatan.

Menurut Smeltzer, et al. (2008), menerangkan bahwa fisiologis fungsi paru dapat diukur dengan spirometry/ peak flowmeter untuk menilai FEV1. Rerata pada 1 (satu) jam paska ekstubasi hanya yang mampu mencapai nilai FEV1 tidak lebih dari $160 \mathrm{~mL} / \mathrm{min}$. Hal ini menunjukkan bahwa kondisi awal paru paska ekstubasi yang sangat lemah, tetapi setelah menjalani perawatan, meningkat hingga $275 \mathrm{~mL} / \mathrm{min}$.

Beberapa kondisi seperti PPOK dan penyakit pernapasan lainnya menunjukkan nilai kapasitas vital paru dalam kondisi normal hanya sekitar 200-300 $\mathrm{mL} / \mathrm{min}$, sehingga nilai rerata FEV1 dari hasil penelitian ini menggambarkan bahwa responden mempunyai faktor penyebab berupa gangguan pernapasan. Peningkatan rerata nilai FEV1 yang tidak dapat melebihi $275 \mathrm{~mL} / \mathrm{min}$ merupakan hasil terbaik yang diperoleh, mengingat rerata responden mempunyai faktor penyakit paru. Klien dengan penyakit paru telah terbiasa dengan kondisi kapasitas vital yang rendah.

Mulai 1 (satu) jam paska ekstubasi sampai hari ke-5, saturasi oksigen telah mencapai nilai di atas 97\%. Hal tersebut berkenaan syarat klien dapat dilakukan weaning dan ekstubasi bila $\mathrm{SaO} 2$ cukup adekuat lebih dari 95\%. Menurut Guyton dan Hall (2006) dan Price dan Wilson (2006), yang menjelaskan bahwa proses transportasi oksigen dan oksigenasi jaringan secara lansung dipengaruhi oleh sistem kardiovaskuler dan he- matologi yang didukung status fungsi paru yang memadai.

Saturasi oksigen juga ditentukan oleh proses kimiawi oksihemoglobin dalam tubuh. Nilai $\mathrm{SaO} 2$ selama perawatan hari ke-2 sampai hari ke-5, menunjukkan DBE tidak berdampak terhadap penurunan nilai di bawah normal, artinya tidak ada efek yang merugikan dari latihan tersebut. Hal tersebut searah dengan pola pernapasan dan kapasitas vital paru yang mampu ditingkatkan dengan baik selama perawatan sampai hari ke-5, sehingga oksigenasi ke jaringan masih tetap adekuat.

\section{Kesimpulan}

Penelitian ini menemukan pengaruh positif DBE terhadap fungsi VO paru hari ke-2, 3, 4, dan 5. Ada perbedaan yang bermakna pada fungsi VO paru, pola pernapasan dan kapasitas vital paru pada hari ke-4 dan 5 antara kelompok intervensi dan kontrol tetapi tidak ada perbedaan untuk saturasi oksigen pada hari-2, 3, 4 dan 5.Perawat perlu menerapkan DBE dalam asuhan keperawatan. Penetapan DBE sebagai terapi modalitas keperawatan seharusnya menjadi pertimbangan pengelola RS.

Bagi institusi pendidikan untuk dapat memasukkan DBE sebagai bahan pembelajaran praktik klinik dengan memperhatikan kajian terbaru ilmu keperawatan. Peneliti berikutnya diperlukan untuk mengidentifikasi efektifitas manajemen pernapasan terhadap keberhasilan weaning ventilasi mekanik (INR).

\section{Referensi}

Anne, T., Pippin H., \& Hill S. (2009). Coughdeep breathing exercises. Diperoleh dari http://phicare.com/docs/clinical/B160pdf.

El-Batanouny, M.M., Amin, M.A., Salem, E.Y., \& El-Nahas, H.E. (2009). Effect of exercise on ventilatory function in welders. Egyptian Journal of Bronchology, 3 (1), 67 - 73. 
Guyton, A.C., \& Hall, J.E. (2006). Textbook of medical physiology (11th Ed.). Philadelphia: WB. Saunders Company.

Ignatavicius, D.D., \& Workman, M.L. (2006). Medical surgical nursing: Critical thinking for collaborative care (5th Ed., Vol. 2). St. Louis: Elsevier Saunders.

Nusdwinuringtyas, N. (2008). Efek latihan otot-otot pernapasan pada penyakit paru obstruksi kronis di Instalasi Rehabilitasi Medik RSUPN Dr. Cipto Mangunkusumo Jakarta (Master Tesis, tidak dipublikasikan). Program Pascasarjana Fakultas Kesehatan Masyarakat Universitas Indonesia, Depok - Jawa Barat.

Padula, C.A., \& Yeaw E. (2006). Inspiratory muscle training: integrative review. Research and Theory for Nursing Practice: An International Journal, 20 (4), 291-304. Doi: 10.1891/rtnp$\mathrm{v} 20 \mathrm{i} 4 \mathrm{a} 005$

Price, S.A., \& Wilson, L.M. (2006). Pathophysiology: Clinical concepts of disease process (6th Ed.). Philadelpia: Elsevier Science.
Rodriguez, P., Dojat, M., \& Brochard, L. (2005). Mechanical ventilation: changing concepts. Indian Journal of Critical Care Medicine [serial online], 9 (4), 235-243. Doi: 10.4103/09725229.19765 .

Smeltzer, S.C., Bare, B.G., Hinkle, J.L., \& Cheever, K.H. (2008). Brunner \& Suddarth's Textbook of Medical-Surgical Nursing (11th Ed.). Philadelphia, PA: Lippincott, Williams \& Wilkins.

Westerdahl, E., Linmark, B., Eriksson, T., Friberg, O., Hedenstierna, G., \& Tenling, A. (2005). Deep-breathing exercises reduce atelectasis and improve pulmonary function after coronary artery bypass surgery. Chest, 128 (5), 34823488. Doi: $10.1378 /$ chest.128.5.3482

Yadav A., Singh S., \& Singh K.P. ( 2009). Role of pranayama breathing exercise in rehabilitation of coronary artery disesase patient-a pilot study. Indian Journal of Traditional Knowledge, 8 (3), 455-458. 